\title{
A Partially Purified Preparation of Isolated Chemosensory Cilia from the Olfactory Epithelium of the Bullfrog, Rana catesbeiana
}

\author{
Robert R. H. Anholt, ${ }^{\star}$ Ueli Aebi, $\uparrow$ and Solomon H. Snyder ${ }^{\star}$ \\ *Departments of Neuroscience, Pharmacology and Experimental Therapeutics, Psychiatry and Behavioral \\ Sciences, and the tDepartment of Cell Biology and Anatomy, The Johns Hopkins University School of Medicine, \\ Baltimore, Maryland 21205
}

\begin{abstract}
Cilia at the tips of dendritic processes of olfactory receptor cells are the sites of initial recognition and transduction events in olfactory reception. We have detached cilia from the olfactory epithelium of the bullfrog, Rana catesbeiana, via a calcium shock and partially purified them in high yield $(226 \pm 19 \mu \mathrm{g}$ protein/ frog, $n=14$ ) by sucrose gradient centrifugation. The cilia appear to undergo osmotic lysis during the isolation procedure, forming isolated axonemal structures and ciliary plasma membrane vesicles with diameters of 100-500 nm and an internal volume of $2.3 \pm 0.5 \mu \mathrm{l} / \mathrm{mg}$ protein. PAGE in SDS reveals approximately 30 protein bands, among which cytoskeletal components, such as tubulin and actin, are readily identifiable by immunoblotting. Approximately 15 glycoprotein bands reactive with concanavalin $\mathrm{A}$ are discernible with major glycopeptides at apparent molecular weights of 56-65, 95, and $116 \mathrm{kDa}$. In contrast to olfactory cilia, respiratory cilia, isolated from the palate of the frog, do not contain the prominent glycopeptides observed for olfactory cilia. The $56-65 \mathrm{kDa}$ glycopeptide region reacts with antiserum against chick kidney, $\mathrm{Na}^{+} / \mathrm{K}^{+}-\mathrm{ATPase}$, and contains the $\beta$ subunit of this enzyme. In addition, we have identified the $\alpha$ and $\beta$ subunits of a quanine nucleotide-binding protein (G-protein) in the olfactory cilia preparation. This preparation of isolated olfactory cilia from Rana catesbeiana represents a readily accessible model system for studies of initial events in chemosensory recognition and signal transduction in the olfactory system.
\end{abstract}

Olfactory reception in vertebrates is mediated via receptor cells located in the olfactory epithelium. These cells are bipolar neurons. They project an axon across the cribriform plate of the ethmoid bone into the glomerular layer of the olfactory bulb, where the first synaptic relay occurs. In addition, they extend a dendrite towards the nasal lumen (for reviews, see Getchell et al., 1985, and Lancet, 1984, 1986). This dendrite carries at its apex a group of cilia that are in contact with the nasal mucus (Getchell et al., 1985; Lancet, 1984, 1986; Menco, 1980; Reese, 1965). The cilia appear to be the site where the initial chemosensory recognition and transduction events take place. This notion is based partly on analogies with sensory organelles of the visual and auditory systems and is supported by several lines of evidence. Lavage of the olfactory epithelium of the frog

\footnotetext{
Received June 27, 1985; revised Oct. 14, 1985; accepted Dec. 30, 1985.
}

This work was supported by a grant from International Flavors and Fragrances, Inc. U.A. is supported by N.I.H. Grant GM-31940 and is the recipient of a research award from the Maurice Müller Foundation of Switzerland. We thank Drs. Pamela Sklar and Doron Lancet for valuable discussions and Dawn C. Dodson for secretarial assistance. We are especially grateful to Naomi Taylor for excellent technical assistance, and to Dr. Eva Neer and Drs. Tamkun and Fambrough for the donation of antisera.

Correspondence should be addressed to Dr. Snyder, Department of Neuroscience, 725 North Wolfe Street, Baltimore, MD 21205.

Copyright (c) 1986 Society for Neuroscience $0270-6474 / 86 / 071962-08 \$ 02.00 / 0$ with Triton X-100 removes the cilia while leaving the rest of the receptor cells intact. This results in the abolition of the electro-olfactogram, a complex electrical signal observed after odor application. The return of the electro-olfactogram is correlated with the reappearance of olfactory cilia (Adamek et al., 1984). Electron-microscopic observations of freeze-fracture replicas reveal numerous particles in membranes of cilia from olfactory epithelium, while only few particles are detected in cilia from respiratory epithelium (Menco, 1980; Menco et al., 1976). In addition, Rhein and Cagan (1980) have described binding sitcs for odorant amino acids on cilia isolated from the olfactory rosette of the rainbow trout.

Techniques for the detachment of cilia were initially developed for studies on protozoa (Adoutte et al., 1980), such as paramecium and tetrahymena (Gibbons, 1965; Watson and Hopkins, 1962) and lamellibranch mollusks (Linck, 1973). Based on these studies, Rhein and Cagan (1980) applied a calcium shock to detach and isolate cilia from the olfactory organ of the rainbow trout. Subsequently, Chen and Lancet (1984) reported the isolation of olfactory cilia from the frog, Rana ridibunda, using a similar method. The frog is eminently suitable for morphological, electrophysiological, and developmental studies of the olfactory system. The olfactory and respiratory epithelia are well separated. The olfactory epithelium is readily accessible and consists of a dorsal and a ventral sheet that can easily be dissected. The olfactory cilia have been reported to reach lengths of up to $200 \mu \mathrm{m}$ (Reese, 1965) and can be readily detached from the epithelium.

We shall describe a procedure by which a preparation enriched in olfactory cilia can be obtained from the bullfrog, Rana catesbeiana. The bullfrog yields up to 7 times more material per animal than the smaller frogs, such as Rana ridibunda and Rana pipiens. We also describe some of the major ultrastructural and biochemical characteristics of this preparation.

\section{Materials and Methods}

\section{Isolation of olfactory cilia}

Rana catesbeiana $(20-25 \mathrm{~cm})$ were supplied by Amphibians of North America (Nashville, TN) or Acadian Biological (Rayne, LA). Rana pipiens were obtained from Nasco (Ft. Atkinson, WI). The animals were maintained in a well-ventilated facility in a tank with circulating water. Frogs were killed by decapitation, and the ventral and dorsal sheets of olfactory epithelia were removed from both nasal chambers. The palate was dissected for the preparation of respiratory cilia. The tissues were bathed for $20 \mathrm{~min}$ in ice-cold Ringer's solution supplemented with 2 mM EDTA to dissolve the mucus. During this incubation period the solution was replaced twice with fresh solution. Subsequently, the medium was replaced with ice-cold Ringer's solution supplemented with $10 \mathrm{mM} \mathrm{CaCl}_{2}$, and the tissuc gently agitated on an end-over-end shaker for $10 \mathrm{~min}$ at $4^{\circ} \mathrm{C}$. The deciliated epithelia were removed by centrifugation for $2 \mathrm{~min}$ at medium speed in a Clay-Adams Dynac serological centrifuge. The supernatant containing the detached cilia was centri- 
fuged once again and the resulting supernatant (usually $3 \mathrm{ml}$, containing cilia from one frog $/ \mathrm{ml}$ ) was layered on top of $2 \mathrm{ml} \mathrm{of} 45 \%$ (wt/wt) sucrose in Ringer's solution. The gradients were centrifuged at $4^{\circ} \mathrm{C}$ for $30 \mathrm{~min}$ at $350,000 \times g$ in a Beckman SW55Ti rotor. The cilia were collected from the interface on top of the sucrose cushion, diluted in an equal volume of Ringer's solution, and pelleted by centrifugation at $4^{\circ} \mathrm{C}$ for $15 \mathrm{~min}$ at $350,000 \times g$ in the SW55Ti rotor. The pellet was resuspended in a small volume of Ringer's solution containing 2 mM EGTA. The protein concentration of the suspension was measured according to the method of Lowry et al. (1951), using BSA as standard. Cytochrome oxidase activity, used as an index of contamination, was assayed by a polarographic method, as described previously (Anholt et al., 1986). The concentrated suspension of isolated cilia could be stored at $-70^{\circ} \mathrm{C}$.

\section{Measurement of apparent internal volume}

The apparent internal volume of the cilia preparation was measured by incubation of an aliquot of the cilia suspension with $0.5-1.0 \mu \mathrm{Ci}$ of ${ }^{86} \mathrm{Rb}^{+}$(New England Nuclear, Boston, MA) for $48 \mathrm{hr}$ at $4^{\circ} \mathrm{C}$. Internal ${ }^{86} \mathrm{Rb}^{+}$was separated from the external radioisotope, as described by Gasko et al. (1976), by passage through a Dowex 50W8X cation exchange resin equilibrated in the Tris form. Assays were performed in triplicate and the column eluates counted with a scintillation counter after addition of Formula 963 scintillation cocktail (New England Nuclear, Boston, MA).

\section{Electron microscopy}

For electron-microscopic examination, olfactory cilia were pelleted by centrifugation and the pellets fixed for $3 \mathrm{hr}$ with $2.5 \%$ glutaraldehyde (Electron Microscopy Sciences, Ft. Washington, PA) in Ringer's solution containing $1 \mathrm{mM} \mathrm{CaCl}$. After overnight incubation in ice-cold buffer, the pellets were postfixed for $1 \mathrm{hr}$ with ice-cold $1 \% \mathrm{OsO}_{4}$ (Electron Microscopy Sciences), dehydrated through a graded series of ethanol, and embedded in Araldite 6005 (Electron Microscopy Sciences). Sections ( $80 \mathrm{~nm}$ ) were cut on a Sorvall Porter-Blum MT2B ultramicrotome and the specimens were examined under a Zeiss EM9S-2 electron microscope at $60 \mathrm{kV}$.

For negative staining, samples $(\sim 3 \mu \mathrm{l})$ were placed on carbon-coated 400-mesh/in. copper grids, which were briefly blotted with a drop of Ringer's solution to render them wet. After $60 \mathrm{sec}$, the grids were blotted with filter paper and washed for $30 \mathrm{sec}$ upside-down on several drops of Ringer's solution and subsequently water. Finally, they were negatively stained for $30 \mathrm{sec}$ upside-down on several drops of $0.75 \%$ uranyl formate, $\mathrm{pH} 4.25$. Before the grids were allowed to dry, excess stain was blotted with filter paper and further drained off by gentle suction with a capillary.

Specimens were examined in a Zeiss EM10C transmission electron microscope operated at an acceleration voltage of $80 \mathrm{kV}$. Electron micrographs were recorded at either 5000 or $25,000 \times$ nominal magnification on Kodak SO-163 electron image film and developed for $4 \mathrm{~min}$ in $3 \times$ diluted Kodak D-19 developer. Magnification was calibrated using negatively stained catalase crystals, as described by Wrigley (1968).

\section{$P A G E$ and electrophoretic transfer}

PAGE in SDS was performed after treatment of the samples with 2-mercaptoethanol on $10 \%$ slab gels in the discontinuous buffer system of Laemmli (1970). Protein bands were visualized by the silver-stain method of Wray et al. (1981). Myosin (205 kDa), $\beta$-galactosidase (116 $\mathrm{kDa})$, phosphorylase $\mathrm{B}(97.4 \mathrm{kDa}), \mathrm{BSA}(66 \mathrm{kDa})$, ovalbumin $(45 \mathrm{kDa})$, glyceraldehyde-3-phosphate dehydrogenase $(36 \mathrm{kDa})$, carbonic anhydrase $(29 \mathrm{kDa})$, trypsinogen $(24 \mathrm{kDa})$, and trypsin inhibitor $(20.1 \mathrm{kDa})$, all obtained from Sigma, were used as molecular weight markers. Electrophoretic transfer of proteins onto a nitrocellulose membrane (Schleicher and Schuell, Keene, NH) was performed at $10^{\circ} \mathrm{C}$ for $2 \frac{1 / 2}{\mathrm{hr}}$ at $80 \mathrm{~V}$ in a TE50 Transphor unit (Hoefer Scientific Instruments, San Francisco, CA) in $25 \mathrm{~mm}$ Tris, $192 \mathrm{~mm}$ glycine, $20 \%$ (vol/vol) methanol, $\mathrm{pH}$ 8.3. After transfer, the gel was silver-stained to ascertain that the transfer of proteins was complete. The membrane was stained with amido black or stored at $4^{\circ} \mathrm{C}$ in $50 \mathrm{~mm}$ Tris- $\mathrm{HCl}, 1 \mathrm{~mm}$ EDTA, $0.1 \%$ gelatin, $0.1 \%$ Triton $\mathrm{X}-100, \mathrm{pH} 7.7$.

\section{Immunoblotting}

Monoclonal antibodies against $\alpha$ and $\beta$ tubulin from bovine brain were generously donated by Dr. Steve Blose (Cold Spring Harbor Laboratories, Long Island, NY). Monoclonal anti-actin was obtained from
Amersham (Arlington Heights, IL). Rabbit antisera against the $\alpha$ and $\beta$ subunits of a G-protein purified from cortex of rat brain were generously provided by Dr. Eva Neer (Brigham and Women's Hospitals, Boston, MA) and are described by Huff et al. (1985). Rabbit antiserum against the $\mathrm{Na}^{+} / \mathrm{K}^{+}$-ATPase purified from chick kidney was donated by Drs. Michael Tamkun and Douglas Fambrough (Carnegie Institute of Washington, Baltimore, MD) and is described by Tamkun and Fambrough (1986).

For immunoblotting, nitrocellulose blots were cut into narrow strips which were incubated for $1 \mathrm{hr}$ at room temperature in $10 \mathrm{~mm}$ sodium phosphate buffer, $\mathrm{pH} 7.5,0.9 \% \mathrm{NaCl}, 0.05 \%$ Triton $\mathrm{X}-100$, containing the desired antiserum at the appropriate dilution. Bound antibody was detected using the Vectastain kit from Vector Laboratories (Burlingame, CA). The reaction is based on the formation of complexes of biotinylated secondary antibody, avidin, and biotinylated HRP. The complexes were visualized in $10 \mathrm{~mm}$ sodium phosphate, $\mathrm{pH} 7.5,0.9 \% \mathrm{NaCl}$, containing

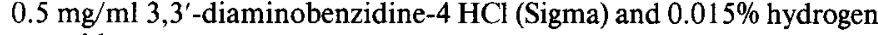
pcroxide.

\section{Results}

\section{Preparation of isolated olfactory cilia}

Prior to the isolation of chemosensory cilia from the olfactory epithelium of the bullfrog, the dissected tissue is incubated in the presence of EDTA to remove the mucus. The cilia are then detached by the addition of an excess of calcium ions. After removal of the deciliated epithelia, the cilia can be collected from the medium by centrifugation. Electron micrographs of this preparation show numerous ciliary structures, which, in cross section, display the characteristic $9+2$ axonemal core (Fig. $1 A$, arrows). In addition, some contaminating material is sometimes observed, which at higher magnification is seen to contain pigment granules and appears, therefore, to be derived largely from melanocytes in the base of the lamina propria (Fig. $1 A$, arrowheads). These contaminants sediment as a black pellet after centrifugation on a $45 \%$ (wt/wt) sucrose cushion, leaving a white band of cilia at the interface with the sucrose cushion. The cilia are diluted with Ringer's solution and collected by centrifugation. They appear to be highly fragile and most of them undergo lysis during the isolation procedure. Electron micrographs reveal axonemes mostly devoid of a surrounding plasma membrane, as well as numerous membrane vesicles ranging from 100 to $500 \mathrm{~nm}$ in diameter (Fig. $1 B$ ). Many of these vesicles appear to be derived from ciliary plasma membranes, as is evident from examination of the preparation after negative staining (Fig. 2). Electron micrographs of negatively stained preparations reveal axonemal structures that, along their entire lengths, appear to be associated with numerous membrane fragments that adhere to or detach from the axonemal cores, forming isolated membrane vesicles (Fig. 2). The negatively stained cilia have a bipolar appearance. One end frequently appears branched, revealing splits along the length of the cilium, as was previously described by Reese (1965), and probably corresponds to the distal end. The other end may represent the detachment site near the ciliary necklace (Fig. $2 a$ ). Equilibration of the preparation for $48 \mathrm{hr}$ with ${ }^{86} \mathrm{Rb}^{+}$indicates an internal volume of $2.3 \pm$ $0.5 \mu \mathrm{l} / \mathrm{mg}$ protein $(n=4)$. Cytochrome oxidase activity, indicative of mitochondrial contamination, amounts to $6.5 \pm 0.2$ nanoatoms of oxygen $/ \mathrm{min} / \mathrm{mg}$ protein $(n=3)$. It is difficult to obtain a precise measurement for the activity of cytochrome oxidase in homogenates from whole olfactory epithelium because of the presence of a large amount of pigmented particulate debris, which appears to interfere with the assay. However, we estimate the specific activity of the enzyme in the whole epithelium to be at least 10 -fold higher than the specific activity measured for the isolated cilia. The yield of olfactory cilia obtained from Rana catesbeiana amounts to $226 \pm 19 \mu \mathrm{g}$ protein per frog $(n=14)$ and is about $7 \times$ higher than the yield of cilia obtained from Rana pipiens (32 $\pm 10 \mu \mathrm{g} / \mathrm{ml}$ protein; $n=6$ ), the American counterpart of the Israeli frog, Rana ridibunda, 


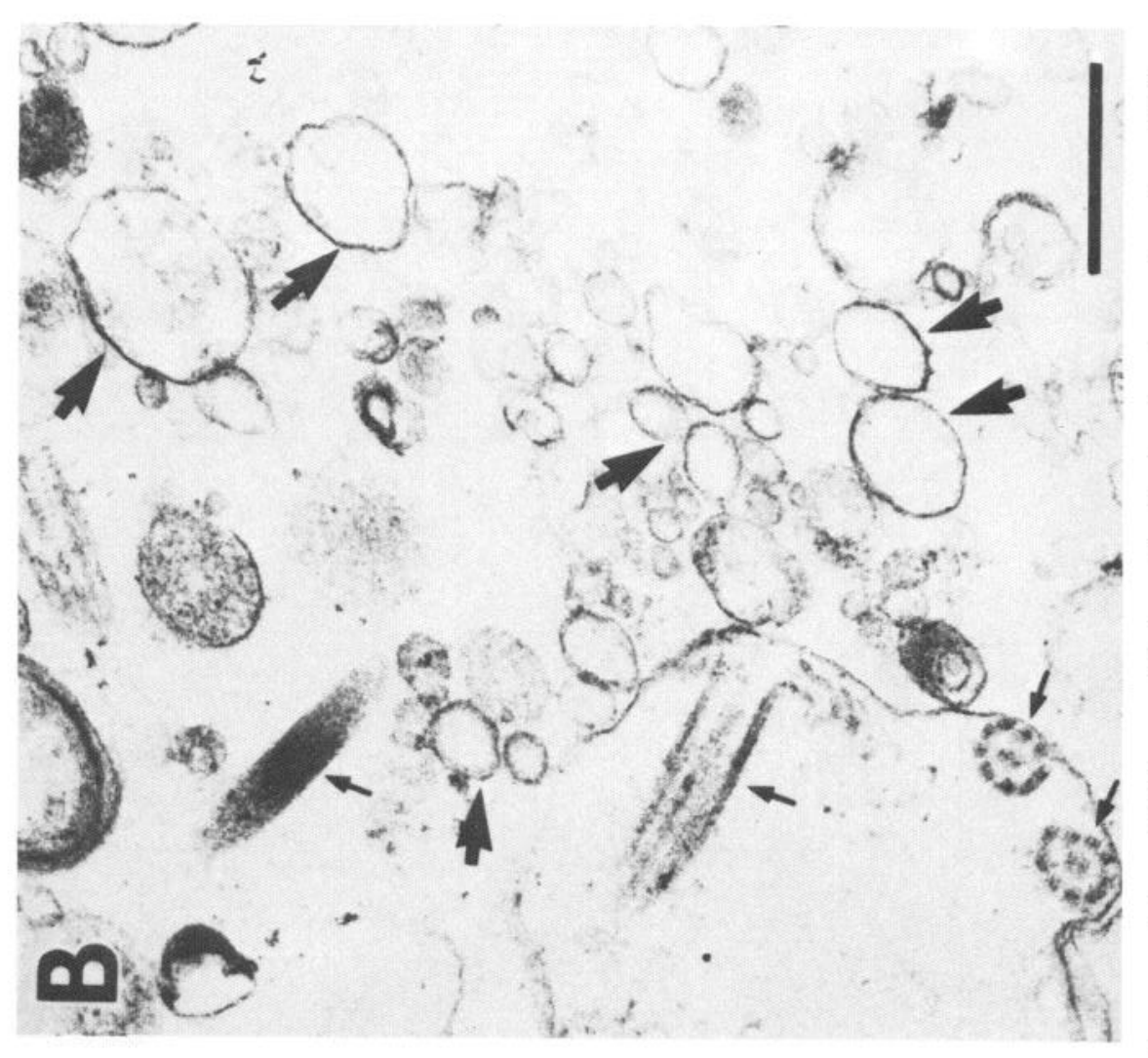

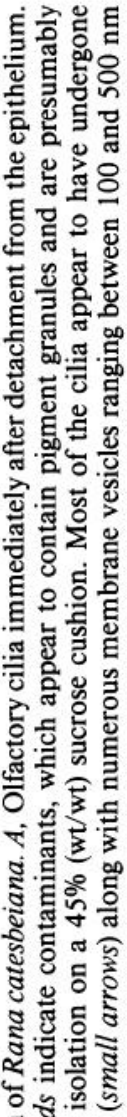

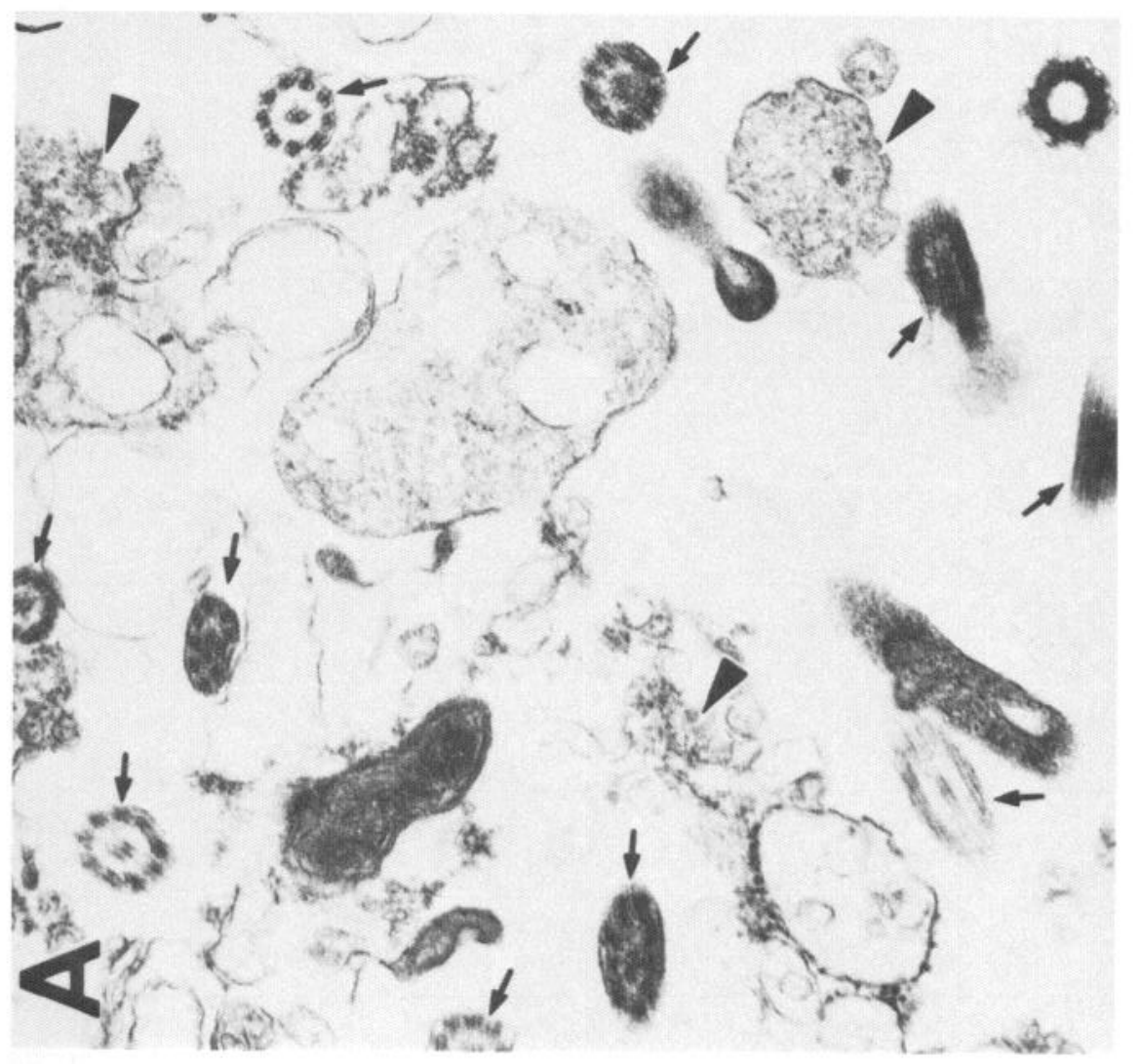

ह 녕

킁 氙

के

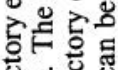

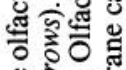

就的

츄. 멸

홍인.

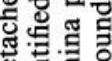

웡틀

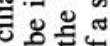

당응

类

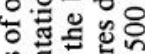

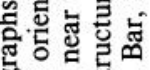

品哇的

율정

동

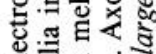

ज्ञा है ह

-

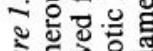

11 

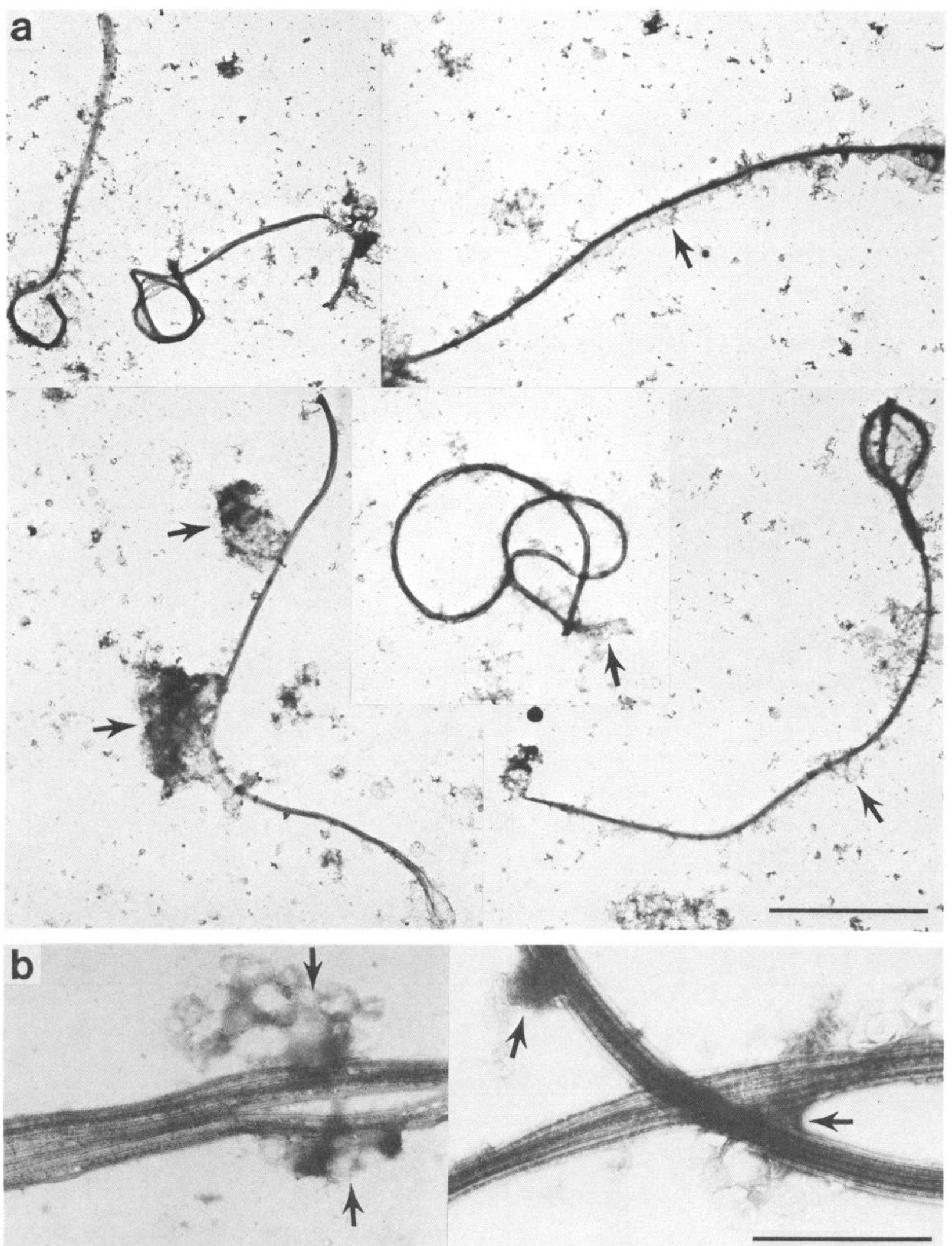

Figure 2. Electron micrographs of negatively stained cilia from the olfactory epithelium of Rana catesbeiana. $a$, Montage of 5 representative fields showing isolated olfactory cilia. In most places the ciliary plasma membrane appears to detach from the axonemes as small membrane fragments or vesicles (arrows), giving rise to many of the vesicular structures seen in Figure 1. $b$, Montage of 2 areas at higher magnification illustrating the ultrastructure of the cilia. Arrays of laterally aggregated microtubules can be clearly discerned. In a few places, indications of transverse connections between adjacent microtubules, presumably dynein arms, can be perceived. Arrows point to ciliary plasma membrane fragments associated with the axonemes. Bars, $5 \mu \mathrm{m}(a) ; 1 \mu \mathrm{m}(b)$. 


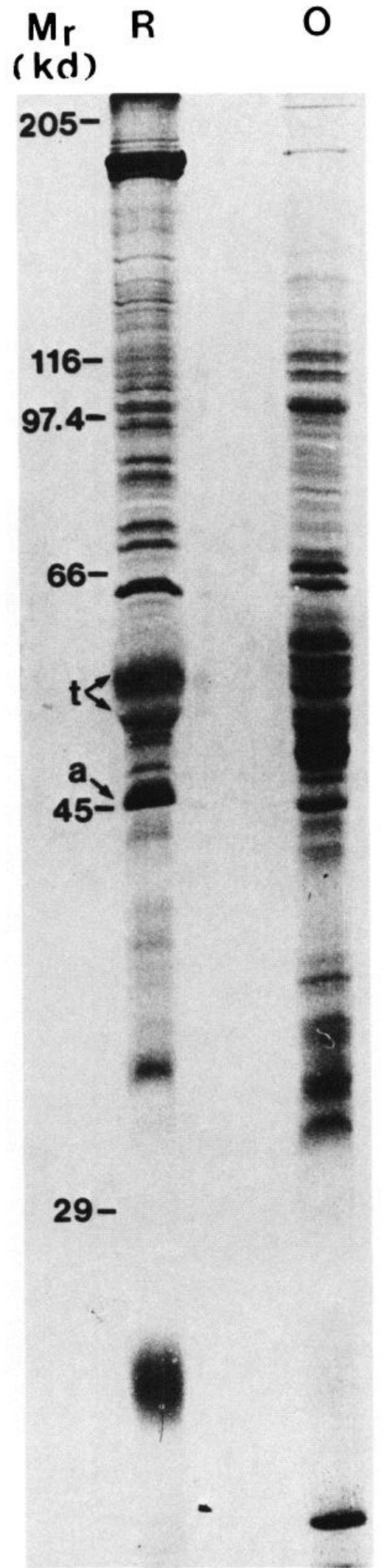

Figure 3. PAGE of isolated olfactory and respiratory cilia. $R$, Respiratory cilia; $O$, olfactory cilia. Each lane contains $30 \mu \mathrm{g}$ protein. $t$, Tubulin dimer; $a$, actin.

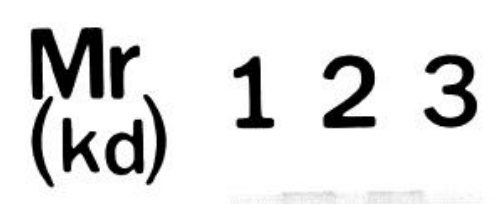

116-
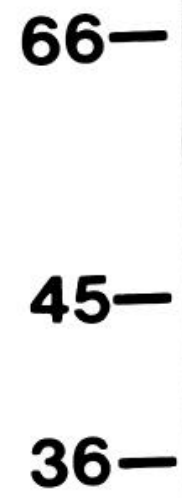

29-

24-

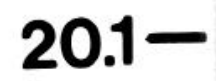

Figure 4. Identification of cytoskeletal proteins of olfactory cilia transferred onto a nitrocellulose membrane. Each strip contains approximately $10 \mu \mathrm{g}$ of ciliary protein. 1, Identification of $\alpha$ tubulin by monoclonal anti- $\alpha$ tubulin. 2, Identification of $\beta$ tubulin by monoclonal anti- $\beta$ tubulin. 3 , Identification of actin by monoclonal anti-actin.

used previously by Chen and Lancet (1984) for the isolation of olfactory cilia.

\section{Biochemical characterization of isolated olfactory cilia}

PAGE in SDS of the olfactory cilia preparation shows a reproducible pattern of bands (Fig. 3). Respiratory cilia isolated by the identical procedure are shown on the sam $\approx$ gel for comparison. The axonemal proteins, $\alpha$ and $\beta$ tubulin, are particularly prominent in the band pattern of the respiratory cilia. In addition, actin is readily detectable, migrating with an apparent molecular weight of $46 \mathrm{kDa}$. A densely stained band at $185 \mathrm{kDa}$, possibly a spectrin-like cytoskeletal protein, is also prominent. As a percentage of the total ciliary protein, these cytoskeletal components are less conspicuous in the olfactory cilia. However, 
they can be readily identified by immunoblotting, which reveals $\alpha$ and $\beta$ tubulin, as well as actin, in the olfactory cilia as 55,53 , and $46 \mathrm{kDa}$ bands, respectively (Fig. 4). At least 30 bands are readily distinguished on silver-stained gels of olfactory cilia, with particularly prominent groups of bands between 31 and 38 $\mathrm{kDa}$ and 48 and $54 \mathrm{kDa}$, in addition to major components at 64, 98, 105, and $110 \mathrm{kDa}$ (Fig. 3).

To detect glycoproteins in isolated olfactory and respiratory cilia, we transferred the gel pattern onto a nitrocellulose membrane and probed it with concanavalin A. About 15 glycoprotein bands are discernible, mostly with apparent molecular weights greater than $55 \mathrm{kDa}$ (Fig. 5). Staining of 3 faint bands, at 74, 78 , and $120 \mathrm{kDa}$, cannot be prevented by the presence of 0.5 $\mathrm{M} \alpha$-methyl-D-mannoside; thus, their glycoprotein nature is ambiguous. Especially prominent staining is observed in a region of $56-65 \mathrm{kDa}$ and of bands at 95 and $116 \mathrm{kDa}$. In contrast, respiratory cilia display only some faint glycoprotein bands, lacking the prominent bands observed in olfactory cilia (Fig. 5).

Previous reports have suggested the involvement of a GTPdependent adenylate cyclase system in olfactory reception $(\mathrm{Ku}-$ rihara and Koyama, 1972; Menevse et al., 1977; Pace et al., 1985). We attempted to identify components of transductory GTP-coupling proteins (G-proteins) in isolated olfactory cilia by immunoblotting (for reviews, see Gilman, 1984, and Schramm and Selinger, 1984). Figure $6 A$ shows a blot of olfactory cilia probed with rabbit antisera raised against a $39 \mathrm{kDa} \alpha$ subunit and a $36 \mathrm{kDa} \beta$ subunit of $\mathrm{G}_{\mathrm{o}}$, a G-protein purified from bovine cortex (Huff et al., 1985). The antiserum against the $\alpha$ subunit of this $\mathrm{G}$ protein reveals a faint band with a molecular weight of $40 \mathrm{kDa}$. The antiserum against the $\beta$ subunit stains a band with a molecular weight of $36 \mathrm{kDa}$. The presence of GTP-binding proteins is not detectable in respiratory cilia using these antisera under identical conditions (Fig. 6B).

If olfactory cilia initiate excitation of the receptor cell, they presumably undergo rapid dissipation of their transmembrane ion gradients during depolarization events. Accordingly, one might anticipate the presence of a Na $\mathrm{Na}^{+} / \mathrm{K}^{+}$-ATPase on the ciliary membrane necessary to maintain and restore the resting potential. This enzyme can, indeed, be identified in the isolated olfactory cilia preparation by immunoblotting with an antiserum raised against a Na$/ / \mathrm{K}^{+}$-ATPase purified from chick kidney (Fig. $6 \mathrm{~A}$ ). The antiserum stains a diffuse region between 56 and 65 $\mathrm{kDa}$, which overlaps the $56-65 \mathrm{kDa}$ region identified with concanavalin A (see above) and corresponds to the expected migration pattern of the $\beta$ subunit of the $\mathrm{Na}^{+} / \mathrm{K}^{+}$-ATPase. The $\alpha$ subunit expected to migrate as a $95-100 \mathrm{kDa}$ species is not recognized by this antiserum. The antiserum reacts only slightly with respiratory cilia (Fig. $6 B$ ).

\section{Discussion}

We have modified previously reported procedures to isolate olfactory cilia at high yield. Earlier protocols employed a $10 \%$ ethanol solution or other organic solvents during the calcium shock-induced detachment of the cilia (Chen and Lancet, 1984; Linck, 1973; Rhein and Cagan, 1980). We observed that the calcium shock alone, in the absence of organic solvent, is equally effective for detaching the cilia from the epithelium. Furthermore, we found the bullfrog, Rana catesbeiana, to be a more convenient source for the isolation of olfactory cilia than the smaller frogs Rana pipiens or Rana ridibunda, since this animal yields $\sim 7 \times$ more ciliary protein per frog. During the isolation procedure most of the cilia undergo lysis, giving rise to isolated axonemal structures and reannealed plasma membrane vesicles (Figs. 1 and 2). The measured internal volume of these vesicles is substantial and would, in principle, allow measurement of radioisotope fluxes across these membranes.

It should be noted that the olfactory cilia preparation is somewhat contaminated by membrane fragments derived from other
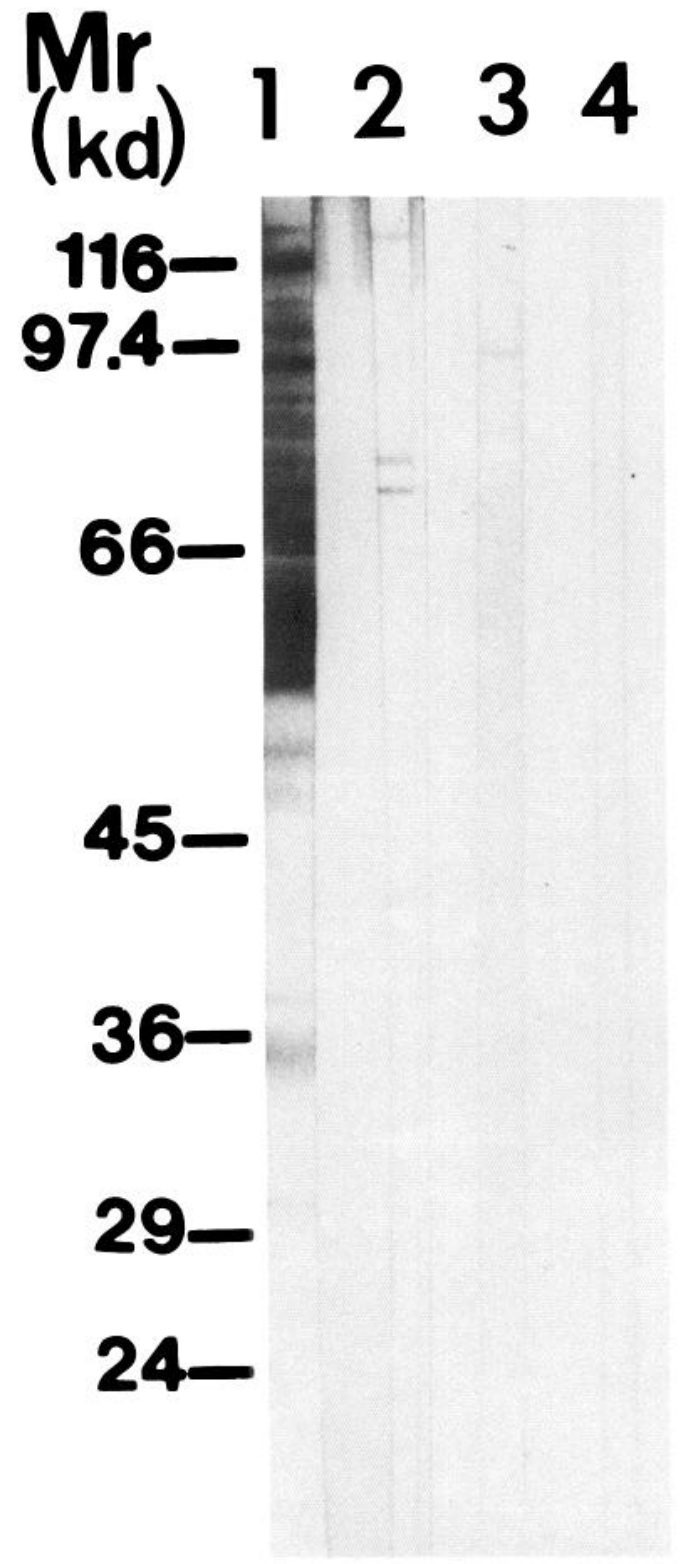

Figure 5. Identification of glycoproteins of olfactory and respiratory cilia transferred onto a nitrocellulose membrane. Each strip contains approximately $10 \mu \mathrm{g}$ of ciliary protein. The strips were probed with concanavalin A $(100 \mu \mathrm{g} / \mathrm{ml}$; Sigma) in the absence ( 1 and 3) or presence (2 and 4) of $0.5 \mathrm{M} \alpha$-methyl D-mannoside. Bound concanavalin A was visualized via an avidin-biotinylated HRP reaction using the Vectastain kit, as described in Materials and Methods, with deletion of the secondary antibody step. Lanes 1 and 2, Olfactory cilia; lanes 3 and 4 , respiratory cilia.

cellular organelles. We have used the mitochondrial marker, cytochrome oxidase, as an index for the extent of this contamination. In contrast to isolated retinal rod outer segments, where rhodopsin can be easily quantitated as a specific marker, it is difficult to precisely evaluate the purity of the olfactory cilia preparation, since no distinct biochemical markers specific for the ciliary membrane have hitherto been identified. The appearance of the preparation after negative staining suggests that a significant number of the observed membrane fragments are derived from the ciliary membrane (Fig. 2). Although we cannot fully exclude the possibility that the membrane proteins and glycoproteins that we identified in the olfactory cilia preparation are localized in part to contaminating organelles, this possibility 
Figure 6. Identification of membrane proteins of olfactory and respiratory cilia transferred onto a nitrocellulose membrane. Each strip contains approximately $10 \mu \mathrm{g}$ of ciliary protein. 1 , Strips incubated with a 200 -fold dilution of normal rabbit serum. 2, Strips incubated with a $200-$ fold dilution of antiserum against the $\alpha$ subunit of $\mathrm{G}_{\mathrm{o}}$ from bovine cortex. 3 , Strips incubated with a 200 -fold dilution of antiserum against the $\beta$ subunit of $\mathrm{G}_{\mathrm{o}}$ from bovine cortex. 4 , Strips incubated with a 500 -fold dilution of antiserum against the $\mathrm{Na}^{+} /$ $\mathrm{K}^{+}$-ATPase from chick kidney.

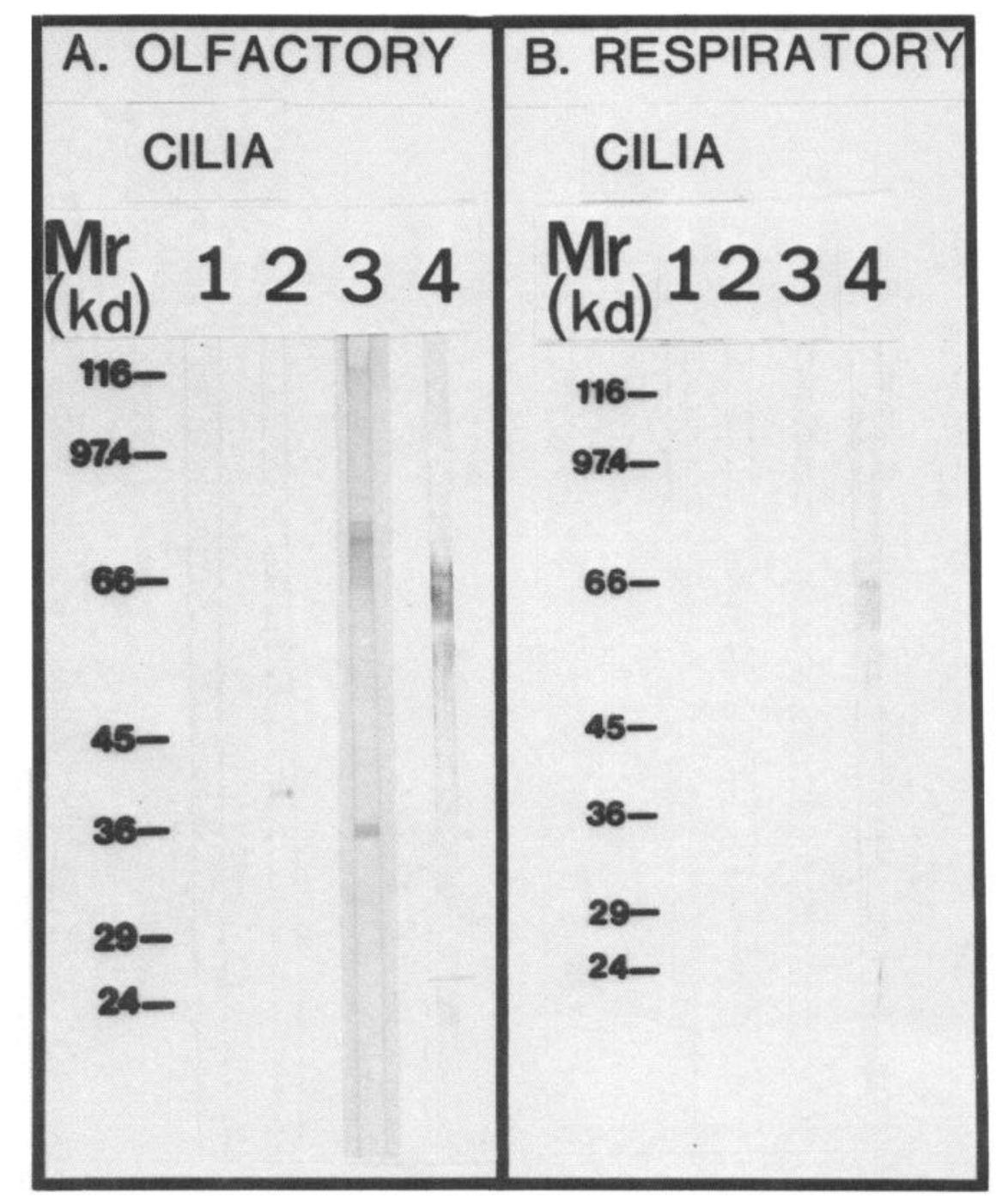

bunda at molecular weights of 55, 58, 95, and $120 \mathrm{kDa}$. These proteins resemble the prominent glycopeptides of 56-65, 95, and $116 \mathrm{kDa}$ observed in our preparations.

A role for cAMP as second messenger in olfactory reception has been suggested by the observations that phosphodiesterase inhibitors reduce the amplitude of the electro-olfactogram (Menevse et al., 1977), that olfactory tissue contains high basal levels

\section{Table 1. Characteristics of isolated cilia from the olfactory and respiratory epithelia of Rana catesbeiana}

\begin{tabular}{|c|c|c|c|c|c|c|c|c|c|}
\hline \multirow[b]{4}{*}{ Characteristic } & \multirow{4}{*}{$\begin{array}{l}\text { Yield } \\
(\mu \mathrm{g} \text { protein/ } \\
\text { frog } \pm \mathrm{SD})\end{array}$} & \multirow{4}{*}{$\begin{array}{l}\text { Internal } \\
\text { volume } \\
(\mu 1 / \mathrm{mg} \text { pro- } \\
\text { tein } \pm \text { SD) }(n)\end{array}$} & \multicolumn{7}{|c|}{ Protein components } \\
\hline & & & \multirow[b]{3}{*}{ Glycoproteins } & \multicolumn{3}{|c|}{ Cytoskeletal proteins } & \multirow{2}{*}{\multicolumn{3}{|c|}{ Membrane proteins }} \\
\hline & & & & & & & & & \\
\hline & & & & Tubulin & Tubulin & Actin & $\mathrm{G}_{\mathrm{o}} \alpha$ & $\mathrm{G}_{0} \beta$ & $\mathrm{Na}^{+} / \mathrm{K}^{+}$-ATPase \\
\hline Olfactory cilia & $226 \pm 19(14)^{a}$ & $2.3 \pm 0.5(4)$ & $\begin{array}{l}\text { Prominent with } \\
\text { major bands at } \\
56-65,95 \text {, and } \\
116 \mathrm{kDa}\end{array}$ & + & + & + & + & + & Prominent \\
\hline Respiratory cilia & $97 \pm 15(4)$ & N.D. ${ }^{b}$ & $\begin{array}{l}\text { Only faint bands } \\
\text { detectable }\end{array}$ & + & + & + & - & - & Barely detectable \\
\hline
\end{tabular}

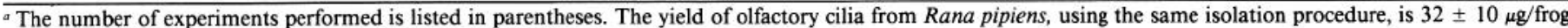
(average of 6 experiments using 89 frogs).

${ }^{b}$ N.D. $=$ not determined. 
of adenylate cyclase activity (Kurihara and Koyama, 1972), and that this activity may be stimulated by at least some odorants in a GTP-dependent manner (Pace et al., 1985; P. Sklar and R. H. Anholt, unpublished observations). Pace et al. (1985) have identified G-proteins in olfactory cilia using cholera toxin- and pertussis toxin-catalyzed ADP-ribosylation. These studies suggested the presence of a G-protein that mediates stimulation of adenylate cyclase, $G_{s}$, and, to a lesser extent, a G-protein that mediates inhibition of adenylate cyclase, $G_{i}$. The latter was resolved as a doublet band after ADP-ribosylation by pertussis toxin, known to use both $G_{i}$ and $G_{o}$ as substrates. We have used an antiserum raised against the $\alpha$ subunit of $\mathrm{G}_{0}$ from bovine cortex, which detects a single polypeptide species at an apparent molecular weight of $40 \mathrm{kDa}$. In addition, an antiserum raised against the $\beta \gamma$ complex of this G-protein reveals a single polypeptide band at $36 \mathrm{kDa}$ (Fig. 6). In most systems studied, it is well established that the $G_{s}$ and $G_{i}$ species play a role in stimulation and inhibition, respectively, of adenylate cyclase (for reviews, see Gilman, 1984, and Schramm and Selinger, 1984). The role of $G_{0}$ is less clear, and it has been suggested that this protein may regulate other transduction systems, such as the phosphatidylinositol cycle (Cockcroft and Gomperts, 1985; Huff et al., 1985). The exact nature and function of the G-proteins found in olfactory cilia and their degree of similarity to retinal transducin or hormonal GTP-coupling protcins remain to bc investigated further. In addition to G-proteins, olfactory cilia appear to contain a $\mathrm{Na}^{+} / \mathrm{K}^{+}$-pump for the maintenance of ionic homeostasis.

The isolated olfactory cilia preparation can be considered analogous to the isolated rod outer segments used for the study of transduction mechanisms in the retina (for a review, see Stryer, 1983). Biochemical studies on isolated olfactory cilia may lead to the establishment of quantitative assays for olfactory recognition and signal transduction in vitro and enable a systematic dissection of the sequence of molecular events that take place between the arrival of the odorant at the cell surface and the generation of an action potential.

\section{References}

Adamek, G. D., R. C. Gesteland, R. J. Mair, and B. Oakley (1984) Transduction physiology of olfactory receptor cilia. Brain Res. 310: 87-97.

Adoutte, A., R. Ramanathan, R. M. Lewis, R. R. Dute, K. Y. Ling, C. Kung, and D. L. Nelson (1980) Biochemical studies of the excitable membrane of Paramecium tetraurelia. J. Cell Biol. 84: 717-738.

Anholt, R. R. H., P. L. Pedersen, E. B. De Souza, and S. H. Snyder (1986) The peripheral-type benzodiazepine receptor: Localization to the mitochondrial outer membrane. J. Biol. Chem. 261: 576-583.

Chen, Z., and D. Lancet (1984) Membrane proteins unique to vertebrate olfactory cilia: Candidates for sensory receptor molecules. Proc. Natl. Acad. Sci. USA 81: 1859-1863.

Cockcroft, S., and B. D. Gomperts (1985) Role of guanine nucleotide binding protein in the activation of polyphosphoinositide phosphodiesterase. Nature 314: 534-536.

Gasko, O. D., A. F. Knowles, H. G. Shertzer, E. M. Suolinna, and E. Racker (1976) The use of ion-exchange resins for studying ion transport in biological systems. Anal. Biochem. 72: 57-65.
Getchell, T. V., F. L. Margolis, and M. L. Getchell (1985) Perireceptor and receptor events in vertebrate olfaction. Prog. Neurobiol. 23: 317345.

Gibbons, I. R. (1965) Chemical dissection of cilia. Arch. Biol. Liege 76: 317-352.

Gilman, A. G. (1984) G proteins and dual control of adenylate cyclase. Cell 36: 577-579.

Huff, R. M., J. M. Axton, and E. J. Neer (1985) Physical and immunological characterization of a guanine nucleotide binding protein purified from bovine cerebral cortex. J. Biol. Chem. 260: 10864 10871.

Kurihara, K., and N. Koyama (1972) High activity of adenyl cyclase in olfactory and gustatory organs. Biochem. Biophys. Res. Commun. 48: $30-34$.

Laemmli, U. K. (1970) Cleavage of structural proteins during the assembly of the head of bacteriophage T4. Nature 227: 680-685.

Lancet, D. (1984) Molecular view of olfactory reception. Trends Neurosci. 7: 35-36.

Lancet, D. (1986) Vertebrate olfactory reception. Annu. Rev. Neurosci. 9: 329-355.

Linck, R. W. (1973) Comparative isolation of cilia and flagella from the lamellibranch mollusc, Aequipecten irradians. J. Cell Sci. 12:345367.

Lowry, O. H., N. J. Rosebrough, A. L. Farr, and R. J. Randall (1951) Protein measurement with the Folin phenol reagent. J. Biol. Chem. 193: 265-275.

Menco, B. P. M. (1980) Qualitative and quantitative freeze-fracture studies on olfactory and nasal respiratory epithelial surfaces of frog, ox, rat and dog. II. Cell apices, cilia and microvilli. Cell Tissue Res. 211: 5-29.

Menco, B. P. M., G. H. Dodd, M. Davey, and L. H. Bannister (1976) Presence of membrane particles in freeze-etched bovine olfactory cilia. Nature 263: 597-599.

Menevse, A., G. Dodd, and T. M. Poynder (1977) Evidence for the specific involvement of cyclic AMP in the olfactory transduction mechanism. Biochem. Biophys. Res. Commun. 77: 671-677.

Pace, V., E. Hanski, Y. Salomon, and D. Lancet (1985) Odorantsensitive adenylate cyclase may mediate olfactory reception. Nature 316: 255-258.

Reese, T. S. (1965) Olfactory cilia in the frog. J. Cell Biol. 25: 209230.

Rhein, L. D., and R. H. Cagan (1980) Biochemical studies of olfaction: Isolation, characterization, and odorant binding activity of cilia from rainbow trout olfactory rosettes. Proc. Natl. Acad. Sci. USA 77:44124416.

Schramm, M., and Z. Selinger (1984) Message transmission: Receptor controlled adenylate cyclase system. Science 225: 1350-1356.

Stryer, L. (1983) Transducin and the cGMP phosphodiesterase: Amplifier proteins in vision. Cold Spring Harbor Symp. Quant. Biol. 47: 841-852.

Tamkun, M. M., and D. M. Fambrough (1986) The $\mathrm{Na}^{+} / \mathrm{K}^{+}-\mathrm{ATPase}$ of chick sensory neurons: Studies on biosynthesis and intracellular transport. J. Biol. Chem. 261: 1009-1019.

Watson, M. R., and J. M. Hopkins (1962) Isolated cilia from Tetrahymena pyriformis. Exp. Cell Res. 28: 280-295.

Wray, W., T. Boulikas, V. P. Wray, and R. Hancock (1981) Silver staining of proteins in polyacrylamide gels. Anal. Biochem. 118: 197203.

Wrigley, N. E. (1968) The lattice spacing of crystalline catalase as an internal standard of length in electron microscopy. J. Ultrastruct. Res. 24: 454-464. 